\title{
Design and Development of Roadside Waste Collector
}

\author{
Manivannan R., Rajasekar R., Nithish Vetrivel S., Praveen Kumar A., Nithesh Kumar K. S.
}

\begin{abstract}
Cleaning has become a basic need of all the human beings. Throughout the world many researchers are conducting experiments in order to eradicate and solve the solid waste removal process. There should be improvising with innovative ideas and techniques which may ensure good health. If an equipment is developed it should be eco-friendly with its usage. All the designer people should be aware of its affects and advantages in preparing a equipment. It's a great task in order to improve the quality and standards of a equipment for its better usage. It should be designed by keeping the ergonomic aspects. Here in this paper it describes the solid waste removal principle and its working which has been prepared by the scrap materials for the domestic purpose only with low cost expenditure. A prototype model is also prepared which uses DC drive powered rotary brush with pneumatic controlled dust shifting which helps user to remove the waste and to maintain clean and hygienic environment and thus avoids health inequalities and safety concerns with regards to workers as well as common people.
\end{abstract}

Keywords: DC Motor, Rotary Brush, Pneumatic Cylinder.

\section{INTRODUCTION}

India is one of the largest countries among the developing nations with large amount of waste products generated day to day life activities. Major amount of wastes generated are thrown along the roadside and only human resources are used to the collect all those wastes. The present method is used to collect the waste materials such as plastic materials, bottles, dust particles by vacuum cleaner. This method is much costlier, more time consuming in nature and affects the human workers in the way of ergonomics. Workers may be affected by Gastro-intestinal infections, respiratory and skin diseases. Thus, in our project the vacuum method is replaced by brushes [Industrial roller brush]. This system helps to remove materials such as solid waste [wood, vegetable wastes etc.,], plastic items etc., This product reduces the human effort, time and power consumption and more economical.

Revised Manuscript Received on December 30, 2019.

* Correspondence Author

Manivannan R., Department of Mechanical Engineering, Kongu Engineering College, Erode (Tamil Nadu) India.

Rajasekar R.*, Department of Mechanical Engineering, Kongu Engineering College, Erode (Tamil Nadu) India.

Nithish Vetrivel S., Department of Mechanical Engineering, Kongu Engineering College, Erode (Tamil Nadu) India.

Nithesh Kumar K. S., Department of Mechanical Engineering, Kongu Engineering College, Erode (Tamil Nadu) India.

PraveenKumar A., Department of Mechanical Engineering, Kongu Engineering College, Erode (Tamil Nadu) India.

(c) The Authors. Published by Blue Eyes Intelligence Engineering and Sciences Publication (BEIESP). This is an open access article under the CC BY-NC-ND license (http://creativecommons.org/licenses/by-nc-nd/4.0/)

\section{METHODOLOGY}

The methodology of this research work has been depicted in Fig.1.

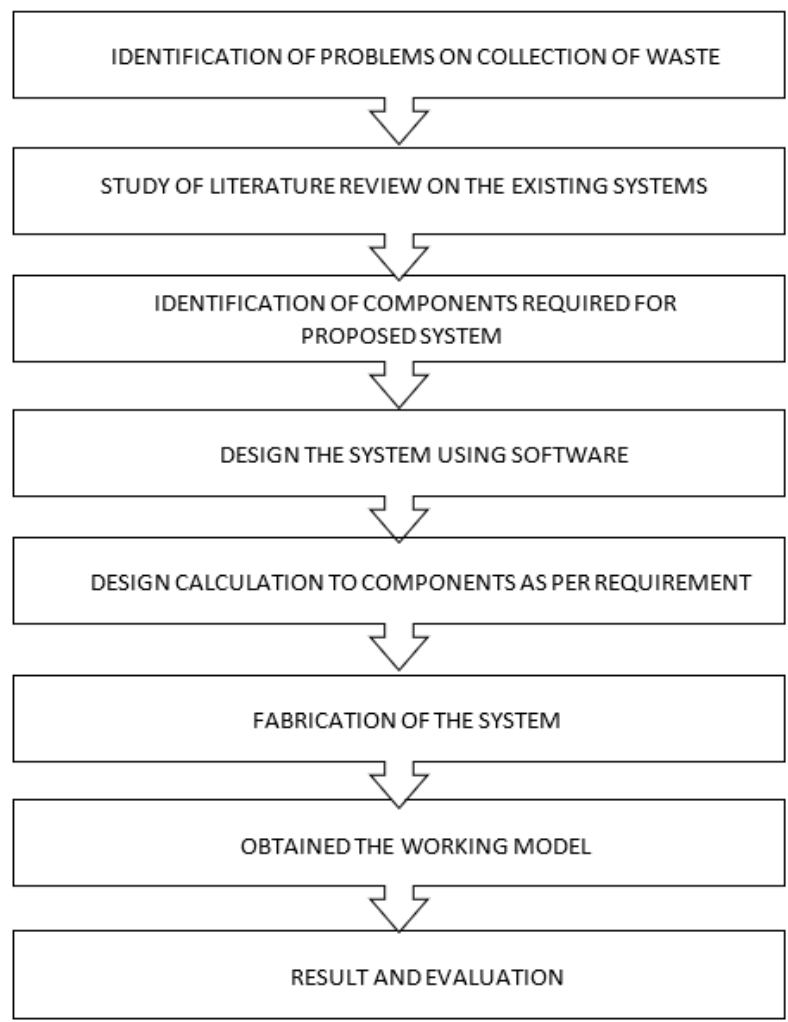

Fig 1 Methodology

III. MATERIALS AND SPECIFICATIONS

Table 1 Materials and its Specifications

\begin{tabular}{|c|c|c|c|}
\hline $\begin{array}{c}\text { COMPONE } \\
\text { NTS }\end{array}$ & $\begin{array}{c}\text { MATERI } \\
\text { ALS }\end{array}$ & PICTURES & $\begin{array}{c}\text { SPECIFICAT } \\
\text { IONS }\end{array}$ \\
\hline $\begin{array}{c}\text { Pneumatic } \\
\text { cylinder }\end{array}$ & Cast Iron & $\checkmark$ & $\begin{array}{c}\text { Stroke }=300 \mathrm{~m} \\
\mathrm{~m} \\
\text { Dia=32mm }\end{array}$ \\
DC Motor & Cast Iron & & $\begin{array}{c}\text { Power }=12 \mathrm{~V}, \\
7 \mathrm{~A} \\
\text { Speed }=90 \mathrm{rpm}\end{array}$ \\
\hline
\end{tabular}

Published By: 


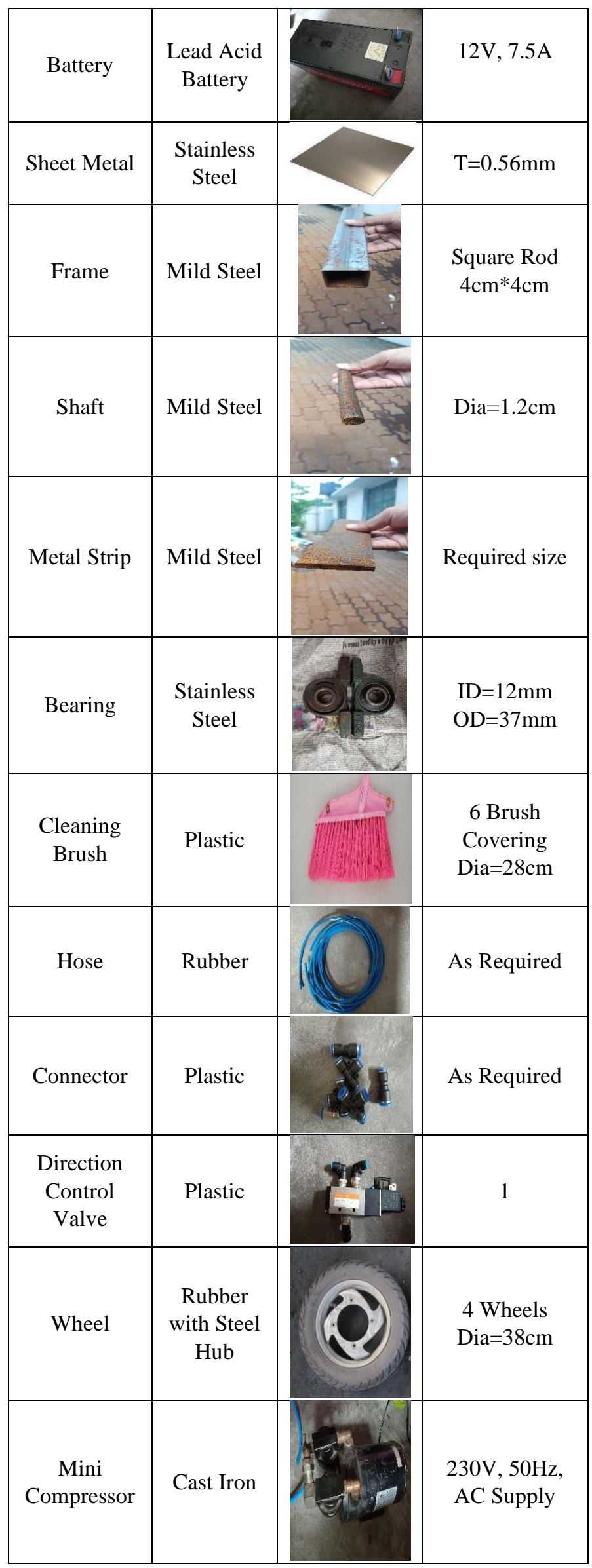

\section{DESIGN CALCULATIONS}

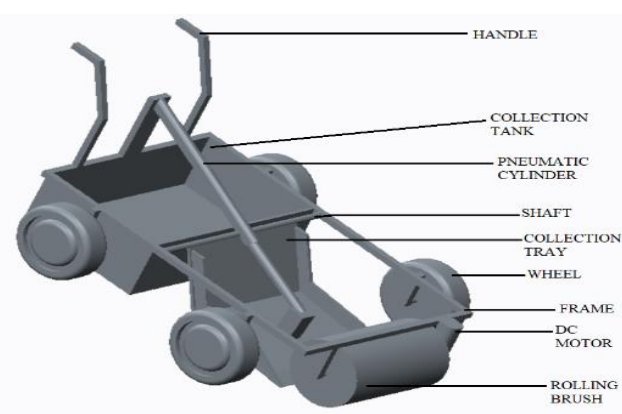

Fig. 2 Proposed Design

Fig 2 represents the proposed design of the project. With the help of this design further calculations and designs are made.

1.Volume of the collection tank $=\mathrm{L} * \mathrm{~B} * \mathrm{H}$

$\mathrm{L}=50 \mathrm{~cm}, \mathrm{~B}=30 \mathrm{~cm}, \mathrm{H}=20 \mathrm{~cm}$

Therefore volume $=50 * 30 * 20=0.03 \mathrm{~m} \wedge 3$

2.Torque of DC motor used, $\mathrm{P}=\left(2 * \mathrm{pi}^{*} \mathrm{~N} * \mathrm{~T}\right) / 60$

$\mathrm{T}=(\mathrm{P} * 60) /\left(2 * \mathrm{pi}^{*} \mathrm{~N}\right)$

$\mathrm{P}=70 \mathrm{~W}, \mathrm{~N}=90 \mathrm{rpm}$

$\mathrm{T}=(70 * 60) /(2 * 3.14 * 90)$

$\mathrm{T}=7.4 \mathrm{Nm}$

3. Load lifting capacity of cylinder

Force $=$ Pressure $*$ Area of cylinder

$\mathrm{P}=2 \mathrm{bar}, \mathrm{d}=0.016 \mathrm{~m}$

$\mathrm{F}=\left(2 * 10^{\wedge} 5\right) *(3.14 / 4 * 0.016 \wedge 2)$

$\mathrm{F}=40.95 \mathrm{~N}$

Load $=4.17 \mathrm{Kg}$

Volume of the collection tank that is provided is $0.03 \mathrm{~m}^{\wedge} 3$. The torque that can be generated by the DC motor used is $7.4 \mathrm{Nm}$. The pneumatic cylinder is fixed to transfer the waste from collection tray to the collection tank. The maximum load that can be lifted by the pneumatic cylinder is approximately $4 \mathrm{Kg}$.

\section{DESIGN ANALYSIS}

Design Process can be carried out by different software such as AUTOCAD, SolidWorks, ProE, Creo, etc., The design process was done entirely by using the CREO 2.0 Software. This software was selected as it is more user friendly and most common software for solid modelling.

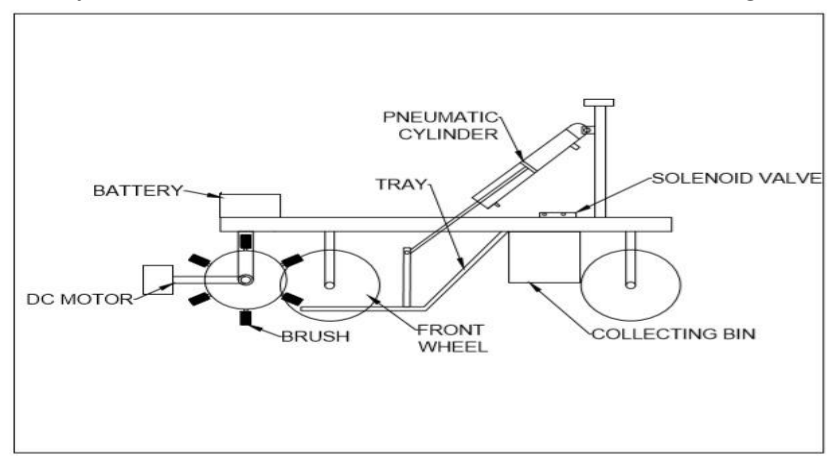

Fig. 32 D Design of the System 

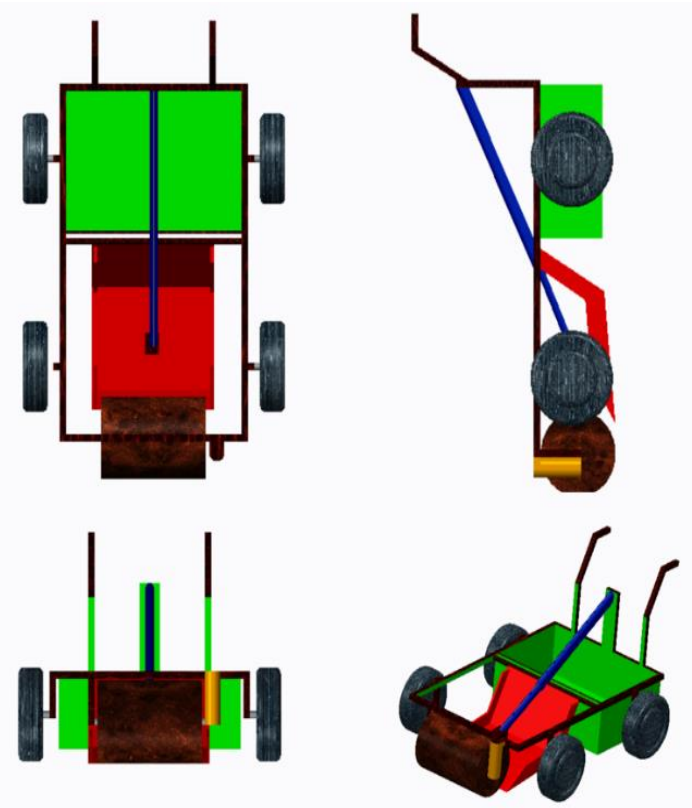

Fig. 4 Views of the System

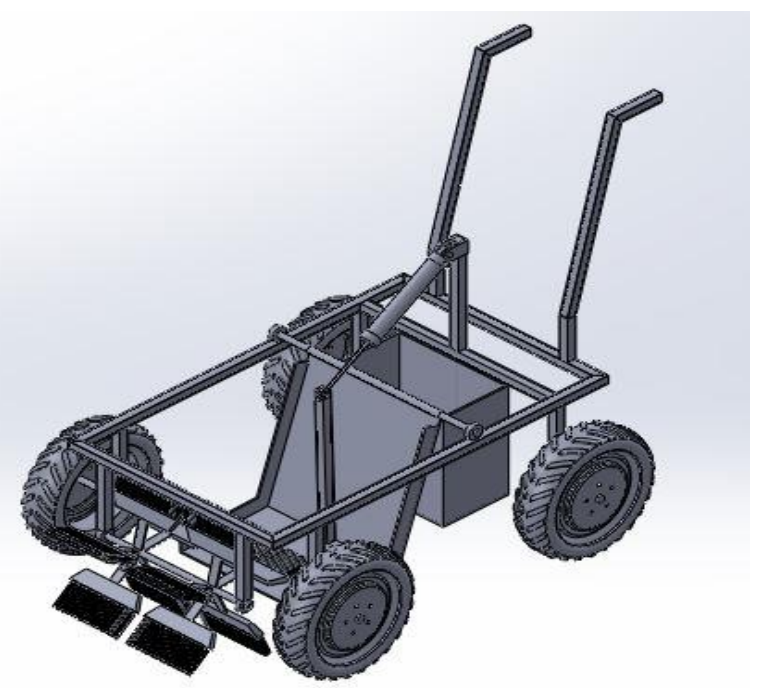

Fig. 5 3D Design of the System

\section{PROPOSED SYSTEM}

The front side of the product consist of the rotating brush coupled to DC motor. Six small brushes are combined to form the rotating brush. The brush is made up of nylon. The main advantage of this brush is that it is flexible and high performing. There is a shaft combining all the small brushes. The middle portion consist of collection tray. Collection tray is a inclined tray in which one end touches the ground and the other end is fixed to a shaft. The collection tray is lifted by using the pneumatic cylinder. The reciprocating motion of the pneumatic cylinder is converted into rotary by using the shaft in which the one side of the collection tray is connected. The shaft relates to bearing on both the ends. The back side consist of main waste collection tank which is made up of sheet metal in the shape of a box opened on the top side.

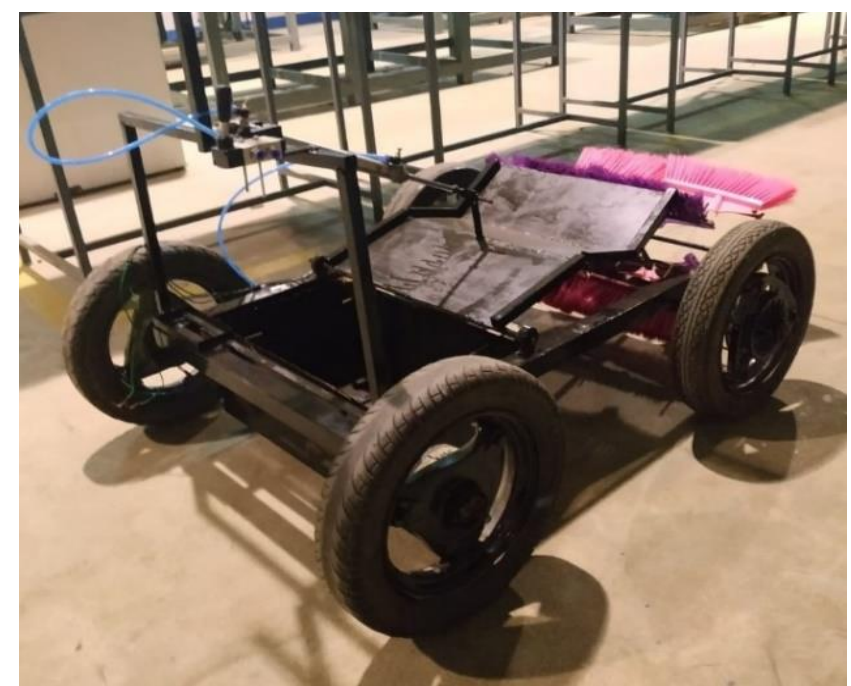

Fig. 6 Fabricated Model

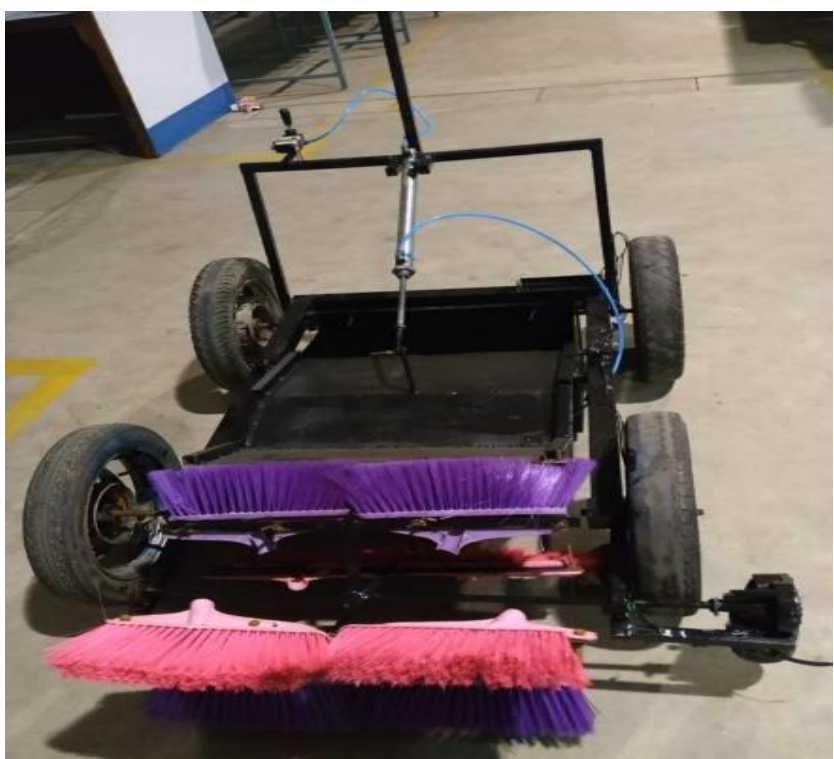

Fig. 7 Fabricated model

\section{WORKING}

The vehicle is placed on the place where the cleaning operation to be done, initially collecting tray is placed in the home position near rotating brush. Once the initial settings are pre checked DC motor gets turned on and tends its shaft to rotate about the fixed axis. This rotation is transferred to the connected rotary brush and makes the waste spread on the surface to force into the collecting tray. Once the collecting tray is filled solenoid valve attached to the pneumatic cylinder gets activated which allows the compressed air to enter the pneumatic cylinder and makes it to extend, this makes collecting tray with dust to shift its position about its fixed hinged point. This causes the dust filled inside tray to shift into the collecting tank from there it is removed. This process is repeated for performing cleaning operation.

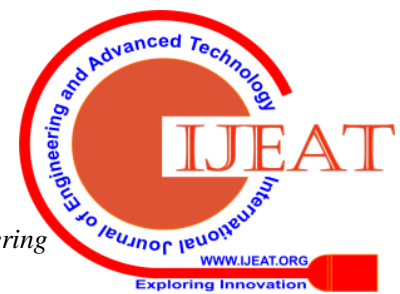




\section{Design and Development of Roadside Waste Collector}

\section{CONCLUSION}

The main motive of the project is to cover ensure cleanliness in the society. It focuses on cleanliness of roads, pathways etc., The multiple applications provide a wide range of functions in which we can clean the waste along roadside, remove metal particles from the road, remove different types of wastes. By application of this technology, we have assembled such a vehicle which has multiple features being cost effective at the same time. The low budget projects are very useful for the society and being low cost and energy efficient that plays a vital role in cleanliness.

\section{REFERENCES}

1. Mr. S. Rameshkumar, M. Selvakumar, S. Senthilkumar, P. Surya, I. Thilagavathi, 2018, Design and Fabrication of Multipurpose Floor Cleaning Machine, International Journal of Advanced Science and Engineering Research.

2. Muhammad KashifShaikh Ghaffar, M. AadilArshad, Nandkishor S. Kale, Ansari M Bilal, Prof. D. M. Ugle, 2018, A Research Paper on "Design and Development of Floor cleaning machine", International Journal of Advance Engineering and Research Development (IJAERD).

3. Dhiraj M. Bankar, Omshree A. Bagnawar, Viki S. Deokar, Prasanth S. Sathe, Khare G. N, 2017, Design and Fabrication of Floor cleaning machine-A review, International Journal of innovations in engineering research and technology [IJIERT]ISSN:2394-3696.

4. Mr. Chavan Abhishek, Mr. Datkhile Pratik, Mr. Khilari Suraj, Mr. More Pratik, Mr. Shinde Sachin, 2018, Manually operated powerless floor cleaning machine, International Journal of Advance Engineering and Research Development.

5. Hussein I. Abdel-Shafy, Mona S.M. Mansour, 2018. Solid waste issue: Sources, composition, disposal, recycling, and valorization. Egyptian Journal of Petroleum (2018).

6. Lilliana Abarca Guerrero, Ger Maas, William Hogland, 2013. Solid waste management challenges for cities in developing countries. Waste Management 33 (2013) 220-232.

7. Vipin Upadhyay, Jethoo A.S, Poonia M. P, 2012. Solid Waste Collection and Segregation: A CaseStudy of MNIT Campus, Jaipur. International Journal of Engineering and Innovative Technology (IJEIT) 1(2012) 2277-3754

8. Daniela Bleck, Wieland Wettberg, 2012. Waste collection in developing countries - Tackling occupational safety and health hazards at their source. Waste Management 32 (2012) 2009-2017.

9. Prathmesh Joshi, AkshayMalviya and PriyaSoni, "Manual Driven Platform Cleaner," IJETAE ISSN 2250- 2459, ISO 9001:2008 Certified Journal,Volume 3, Issue 8, August 2013.

10. Liu, Kuotsan and Wang, Chulun, "A Technical Analysis of Autonomous Floor Cleaning Robots Based on US Granted Patents, ” European International Journal of Science and Technology Vol. 2 No. 7 September 2013.

11. Mohsen Azadbakht, Ali Kiapey, Ali Jafari- —Design and Fabrication of a tractor powered leaves collectorb equipped with suction blower system\| - September, 2014 AgricEngInt: CIGR Journal Open access at http://www.cigrjournal.org Vol. 16, No.3.

12. D Karunakaran, B. Abhilash, V. Ananda prasanna, Design and fabrication of hybrid floor cleaner, international journal of engg research \& Tech(IJERT) ISSN:2278- 0181,Vol.5 Issue 04,april 2016.

\section{AUTHORS PROFILE}

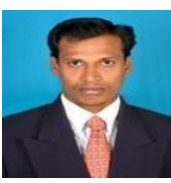

Mr. Manivannan R was born on $31^{\text {st }}$ October 1989. He completed Bachelor of Mechanical Engineering at Dr. Mahalingam College of Engineering and Technology, Tamil Nadu, India in 2011. He obtained his master's degree in Thermal Engineering at Thiruvalluvar College of Engineering and Technology, Tamil Nadu, India in 2013. From 2013, he is working as an Assistant Professor in the Department of Mechanical Engineering at Kongu Engineering College, India

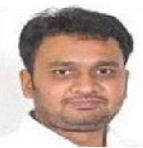

Dr. Rajasekar R. was born on 10th February 1982. He obtained M.S. and Ph.D. degrees in the year 2008 \& 2011 at Indian Institute of Technology, Kharagpur in the stream of Materials Science. He gained Post-Doctoral Research experience during 2011-2012 from the Department of Polymer \& Nano Engineering at Chonbuk National University, South Korea. From 2012, he is working as an Associate Professor in the Department of Mechanical Engineering at Kongu Engineering College, India.

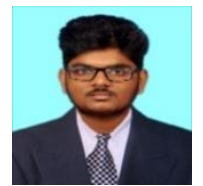

Nithish Vetrivel S. was born on $26^{\text {th }}$ June 1999. He is doing Bachelor of Mechanical engineering at Kongu engineering college, Erode, Tamil Nadu India, in 2019.

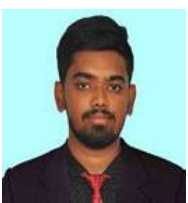

Praveen Kumar. A. was born on $18^{\text {th }}$ September 1999 $\mathrm{He}$ is doing Bachelor of Mechanical engineering at Kongu engineering college, Erode, Tamil Nadu, India, in 2019.

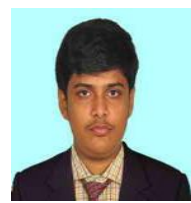

Nithesh Kumar K. S. was born on $12^{\text {th }}$ July $1999 . H e$ is doing Bachelor of Mechanical engineering at Kongu engineering college, Erode, Tamil Nadu, India, in 2019. 